\title{
DIVERSITY OF STAPHYLOCOCCUS COAGULASE- POSITIVE AND NEGATIVE STRAINS OF COALHO CHEESE AND DETECTION OF ENTEROTOXIN ENCODING GENES
}

\author{
ANA PAULA COLARES DE ANDRADE* \\ MARIA DE FÁTIMABORGES * \\ EVÂNIA ALTINA TEIXEIRA DE FIGUEIREDO* \\ EDNA FROEDER ARCURI ***
}

\begin{abstract}
Three hundred samples of coalho cheese, from 15 different brands, seven handmade and eight industrialized, were evaluated in relation to the contamination profile by Staphylococcus coagulase-positive and negative and the occurrence of staphylococcal enterotoxin encoding genes. Two hundred and eight isolates of Staphylococcus $\mathrm{sp}$. were subjected to phenotypic identification and 95 were subjected to genotypic identification through femA gene research and detection of genes (sea, seb, sec, sed, see, seg, seh, sei and sej) encoding enterotoxins, using the polymerase chain reaction technique (PCR). A total of 14 species of Staphylococcus were identified, of which three were coagulase-positive and eleven negative, especially: S. aureus, S. xylosus, S. cohnni spp. cohnii, S. saprophyticus, S. epidermidis, S. hyicus, S. lentus, S. sciuri, S. cohnii spp. urealyticus, S. haemolyticus, S. chromogenes, S. lugdunensis, S. hominis e S. intermedius. In all the samples of handmade coalho cheese there was a prevalence of $\mathrm{S}$. aureus; while at industrial samples $S$. xylosus $(87.5 \%)$ and S. cohnii spp cohnii $(50 \%)$ were predominant. The presence of the femA gene was detected in 95\% (38/40) isolates of positive Staphylococcus coagulase and $16.4 \%$ (9/55) of coagulasenegative isolates. Among the enterotoxin encoding genes evaluated, there was prevalence of the seh gene $(53.2 \%)$ in coagulase-positive strains and of the sec gene $(46.8 \%)$ in coagulase-negative strains. The results suggest a re-evaluation of the Brazilian microbiological standards in relation to the genus Staphylococcus in foods.
\end{abstract}

“CorrespondingAuthor.E-mail:ana.colares@hotmail.com,apcolares@gmail.com;Tel.:+5585987429487Federal University of Ceará, Department of Food Technology, Mister Hull Avenue, 2977, Pici Campus, Block 858, CEP 60356-000, Fortaleza, CE, Brazil.

*Embrapa Tropical Agroindusty, CEP 60511-110, Fortaleza, CE, Brazil.

**Embrapa Dairy Cows, CEP 36038-330, Juiz de Fora, MG, Brazil. 


\section{INTRODUCTION}

Staphylococcus sp. is one of the pathogenic agents most commonly involved in outbreaks of food poisoning. The peculiarities of its habitat makes its presence widely distributed in nature, being transmitted by food handlers ( mostly asymptomatic carriers)and animals, especially dairy cows with mastitis.

Among dairy products, cheeses have been one of the products most often involved in cases of food poisoning, and in the Northeast the emphasis is on coalho cheese. Throughout the region, the production of coalho cheese can be divided into two sectors: the medium-sized companies supervised and regulated by official organizations, and small handmade units, mainly located in rural areas who have nonesupervision (Dantas et al., 2013).

Cheese, especially the handmade kind, drawn mostly from raw milk and, in most cases, poor hygienic conditions, has been considered a source of food-borne pathogens. Therefore, the microbiological safety of the product is of great importance to the health of consumers because of the risk of causing food borne illness.

The level of contamination by coalho cheese because of pathogenic bacteria, especially the Staphylococcus genus, have been high (Tigre; Borelly, 2011; Oliveira et al., 2015; Evangelista-Barreto et al., 2016; Vieira, 2017). These bacteria, when presented in high populations $\left(10^{5}-10^{6} \mathrm{UFC} \mathrm{mL}^{-1} \mathrm{or} \mathrm{g}^{-1}\right)$ and under appropriate conditions (temperature, $\mathrm{pH}$, water activity and $\mathrm{O}_{2}$ ), represents a public health problem because of the ability to produce enterotoxins and cause staphylococcal food poisoning.

Although $S$. aureus is the principal and most studied representative of the genus, the presence and expression of enterotoxins and other virulence factors can be observed in other species of staphylococci, such as coagulase negative staphylococci (Mazzariol et al., 2012; Ünal, Çinar, 2012)

Recently, the list of toxins expanded thanks to the discovery of new genes: 20 distinct types of enterotoxins have been identified so far, however all are similar in structure and sequence. The classical (SEA, SEB, SEC, SEC $_{2}, \mathrm{SEC}_{3}$, SED e SEE) are the most frequent, and thirteen other enterotoxins (SEG, SEH, SEI, SEJ, SEK, SEL, SEM, SEN, SEO, SEP, SEQ, SER E SEU) were identified and their genes (seg, seh, sei, sej, sek, sel, sem, sen, seo, sep, seq, ser and seu) correspondingly described.

The research of genes coding for toxins, through traditional identification and molecular techniques such as the PCR technique and Multiplex PCR, has been a useful tool in the differentiation of Staphylococcus aureus and is therefore a quick and safe alternative for bacteria identification. These methodologies guarantee reliability in the results, besides contributing to minimize the occurrence of foodborne diseases.

Thus, the objective of this study was to identify species of Staphylococcus coagulasepositive and negative strains of coalho cheese and evaluate the occurrence of staphylococcal enterotoxin encoding genes.

\section{MATERIALS AND METHODS}

\subsection{ISOLATION AND PHENOTYPIC IDENTIFICATION OF STAPHYLOCOCCUS SPP}

Staphylococcus spp. was isolated from 300 samples of coalho cheese, from 15 different brands (seven handmade and eight industrial), collected weekly in retail stores in Fortaleza, Brazil from July 2016 to June 2017. The isolation was done in Baird-Parker agar (Merck), according to the methodology described in the literature (Bannerman, 2003, Bennett; Lancette, 2001). After prior screening with conventional biochemical tests (catalase production, coagulase, sensitivity and lisostaphin, fermentation of manitol and glucose and DNAse), 208 isolates, 162 being coagulasepositive and 46 coagulase-negative, phenotype were phenotypically characterized at the species level 
by using the Staphylococcus and Micrococcus identification system (BioMérieux SA, Marcy-l'Etoile - France). S. aureus ATCC 12600 and S. epidermidis ATCC 14990 were used as reference strains.

\subsection{DNA EXTRACTION}

The strains of Staphylococcus sp. had their genetic material extracted according to the protocol described by Rosec and Gigaud (2002), with some changes proposed by Ângelo et al. (2007). Briefly, $2 \mathrm{~mL}$ of the culture were transferred to an Eppendorf tube and centrifuged (High Speed Refrigerated Micro Centrifuge; VS - $15000 \mathrm{CFNII}$ ) at $12.000 \mathrm{~g}$ for 10 minutes. The supernatant was discarded and the cells were re-suspended in $500 \mu \mathrm{L} \mathrm{TE} \mathrm{buffer} \mathrm{[Tris-} \mathrm{HCl} 10 \mathrm{mM} \mathrm{pH} 8.0$ e EDTA 1 $\mathrm{mM} \mathrm{pH}$ 8.0] and centrifuged at $12.000 \mathrm{~g}$ for 10 minutes. Once the supernatant was again discarded, the cells re-suspended in $200 \mu \mathrm{L}$ TE buffer, and $15 \mathrm{~mL}$ of $1 \mathrm{mg} / \mathrm{mL}$ lisostaphin was added to it (Sigma, L7386), mixed (vortex shaker) and incubated at $37{ }^{\circ} \mathrm{C}$ for 30 minutes. Then $10 \mu \mathrm{L}$ of $\mathrm{K} 20 \mathrm{mg} / \mathrm{mL}$ proteinase (Sigma, P6556) were added and the cells were incubated at $60^{\circ} \mathrm{C}$ for 20 minutes and then at $100^{\circ} \mathrm{C}$ for 10 minutes. The total DNA obtained was frozen at $-20^{\circ} \mathrm{C}$ until PCR amplification.

\subsection{POLYMERASE CHAIN REACTION}

The PCR reaction was performed according to methodology described in the literature (Ângelo et al., 2007; Rosec and Gigaud, 2002) using known (oligonucleotide) primers (Table 1). The amplification was performed in a thermo cycler (Techne; TC 512) and contained a mixture of $5 \mu \mathrm{L}$ of PCR 1X (Invitrogen) buffer, $1.0 \mathrm{mM} \mathrm{MgCl}_{2}$ (Invitrogen), $0.2 \mathrm{mM}$ of each dNTP, $0.2 \mu \mathrm{M}$ of each primer (Alpha DNA) and 1.0 U Taq DNA Polymerase Recombinant (Invitrogen). $5 \mu \mathrm{L}$ of extracted DNA were added to the mixture and the volume was completed up to $50 \mu \mathrm{L}$ RNAse-free and DNAse-free (Gibco) distilled water. The amplification conditions were as follows: heating at 94 ${ }^{\circ} \mathrm{C}$ for three minutes, followed by 35 cycles of amplification (denaturation at $94{ }^{\circ} \mathrm{C}$ for 30 seconds, annealing at $57^{\circ} \mathrm{C}$ for 30 seconds and extension at $72{ }^{\circ} \mathrm{C}$ for 30 seconds), final extension at 72 ${ }^{\circ} \mathrm{C}$ for ten minutes and maintenance of the samples at $4{ }^{\circ} \mathrm{C}$ until the gel application. The amplified DNA fragments were visualized in agarose gel 1.5\% (p/v) (Amersham Biosciences) stained with ethidium bromide solution $0.005 \%(\mathrm{p} / \mathrm{v})$ and photographed in documentary photos (Canon; Power Shot A620).

\subsection{RESEARCH OF THE FEMA GENE IN STRAINS OF STAPHYLOCOCCUS AUREUS}

Forty strains of Staphylococcus aureus, composed of 20 isolated strains from handmade coalho cheese and 20 industrialized coalho cheese strains, identified based on conventional biochemical tests and phenotypic tests, were subjected to genotypic confirmation by the amplification of a fragment of $132 \mathrm{pb}$ for the femA gene. The S. aureus ATCC 25923 strain was used as the positive control for the reaction.

\subsection{DETECTION OF ENTEROTOXIN ENCODING GENES}

The research of the staphylococcal enterotoxins encoding genes (sea, seb, sec, sed, see, seg, seh, sei, sej, sel) was performed in 95 strains of Staphylococcus, including coagulase-positive (40) and negative (55), selected among those previously identified by phenotypic tests, through the PCR and Multiplex PCR. In the Multiplex PCR, four conformations were used (sea+sed), (seb+sel), $(\mathrm{sec}+\mathrm{see})$; (seh+sei). Simple PCR was used for single genes seg and sej. S.aureus 95-4776B for sea; S. aureus 91-2415D for seb, S. aureus ATCC 19095 for sec, seh, sei, seg and sel; S. aureus ATCC 23235 for sed, seg, sei and sej; S. aureus ATCC 27664 for see was used as positive controls for the reaction. 


\section{TABLE 1. OLIGONUCLEOTIDE USED IN THE PCR REACTIONS FOR THE AMPLIFICATION OF THE SPECIFIC GENE FOR THE STAPHYLOCOCCUS SPECIES AND DETECTION OF THE STAPHYLOCOCCI ENTEROTOXIN ENCODERS.}

\begin{tabular}{|c|c|c|c|}
\hline Oligonucleotide (5'-3') & Gene(s) & $\begin{array}{l}\text { Amplified } \\
\text { Product }\end{array}$ & Reference \\
\hline $\begin{array}{l}\text { SEA }_{1}: \text { ACG ATC AAT TTT TAC AGC } \\
\text { SEA }{ }_{2} \text { :TGC ATG TTT TCA GAG TTA ATC }\end{array}$ & sea & $544 \mathrm{pb}$ & Betley; Mekalanos (1988) \\
\hline $\begin{array}{l}\text { SEB }_{1}: \text { GAA TGA TAT TAA TTC GCA TC } \\
\text { SEB }_{2}: \text { TCT TTG TCG TAA GAT AAA CTT C }\end{array}$ & seb & $416 \mathrm{pb}$ & Jones; Khan (1986) \\
\hline $\begin{array}{l}\text { SEC }_{1}: \text { GAC ATAAAA GCT AGG AAT TT } \\
\text { SEC }_{2}: \text { AAA TCG GAT TAA CAT TAT CCA }\end{array}$ & sec & $257 \mathrm{pb}$ & Bohach; Schievert (1987) \\
\hline $\begin{array}{l}\text { SED }_{1}: \text { TTA CTA GTT TGG TAA TAT CTC CTT } \\
\text { SED }_{2} \text { : CCA CCA TAA CAA TTAATG C }\end{array}$ & sed & $334 \mathrm{pb}$ & Bayles; Iandolo (1989) \\
\hline $\begin{array}{l}\text { SEE }_{1}: \text { ATA GAT AAA GTT AAA ACA AGC AA } \\
\text { SEE }_{2}: \text { TAA CTT ACC GTG GAC CC }\end{array}$ & see & $170 \mathrm{pb}$ & Couch et al. (1988) \\
\hline $\begin{array}{l}\text { SEG }_{1}: \text { ACG TCT CCA CCT GTT GAA GG } \\
\text { SEG }_{2}: \text { TGA GCC AGT GTC TTG CTT TG }\end{array}$ & seg & $400 \mathrm{pb}$ & Munson et. al (1998) \\
\hline $\begin{array}{l}\mathrm{SEH}_{1}: \text { TCA CAT CAT ATG CGA AAG CAG } \\
\text { SEH }_{2}: \text { TAG CAC CAA TCA CCC TTT CC }\end{array}$ & seh & $357 \mathrm{pb}$ & Ren et al. (1994) \\
\hline $\begin{array}{l}\mathrm{SEI}_{1}: \text { TGG AAC AGG ACA AGC TGAAA } \\
\mathrm{SEI}_{2}: \text { TAA AGT GGC CCC TCC ATA CA }\end{array}$ & sei & $467 \mathrm{pb}$ & Munson et al. (1998) \\
\hline $\begin{array}{l}\text { SEJ }_{1}: \text { CAG CGA TAG CAAAAA TGA AAC A } \\
\text { SEJ }_{2}: \text { TCT AGC GGA ACA ACA GTT CTG A }\end{array}$ & sej & $426 \mathrm{pb}$ & Zhang et al. (1998) \\
\hline $\begin{array}{l}\text { SEL }_{R}: \text { CTG TTT GAT GCT TGC CAT TG } \\
\text { SEL }_{F}: \text { CAC CAG AAT CAC ACC GCT TA }\end{array}$ & sel & $240 \mathrm{pb}$ & Cremonesi et al. (2006) \\
\hline $\begin{array}{l}\text { FEMA }_{1} \text { : AAA AAA GCA CAT AAC AAG CG } \\
\text { FEMA }_{2} \text { : GAT AAA GAA GAA ACC AGC AG }\end{array}$ & femA & $132 \mathrm{pb}$ & Mehrotra et al. (2000) \\
\hline
\end{tabular}

\section{RESULTS AND DISCUSSION}

The coalho cheese samples showed a high population of Staphylococcus $\mathrm{sp}$. The counts ranged from $1.3 \times 10^{6} \mathrm{UFC} / \mathrm{g}$ to $6.6 \times 10^{9} \mathrm{UFC} / \mathrm{g}$ in handmade cheeses and $1.3 \times 10^{7} \mathrm{UFC} / \mathrm{g}$ to $2.9 \times 10^{10}$ UFC/g in industrialized cheese. This level of contamination by Staphylococcus sp. is considered high and may facilitate the production of staphylococcal enterotoxins under suitable environmental conditions.

Astudy carried out on samples of coalho cheese sold in the district of Cabo de Santo Agostinho, PE, Brazil, Oliveira et al. (2010) observed the incidence of Staphylococcus sp. in $76.2 \%$ of the samples, whose counts ranged from $1.6 \times 10^{3}$ to $2.0 \times 10^{5} \mathrm{UFC} / \mathrm{g}$. Similar results were found by Silva Junior (2017), who evaluated samples of coalho cheese sold in Paraiba, Brazil, and found high populations of Staphylococcus sp. $\left(1,1 \times 10^{5} \mathrm{UFC} / \mathrm{g}\right)$ in $100 \%$ of the samples.

Among the 300 samples analyzed, 327 isolated types of Staphylococcus were obtained, 145 of them being coagulase-negative and 182 of them coagulase-positive. After preliminary screening based on conventional biochemical tests, 208 isolated characteristics of the genus were selected. Phenotypic characterization made the identification of 193 isolates (117 of handmade cheeses and 76 industrialized cheeses) possible distributed in 14 species of Staphylococcus, three being coagulase-positive and 11 being coagulase-negative.

There was a prevalence of the species S. aureus (106/193), S. xylosus (40/193), S. cohnni ssp. cohnii (17/193), S. saprophyticus (6/193), S. epidermidis (4/193), S. hyicus (4/193), S. lentus (4/193), S. sciuri (4/193), S. cohnii spp. urealyticus (2/193), S. haemolyticus (2/193), S. chromogenes (1/193), S. lugdunensis (1/193), S. hominis (1/193) and S. intermedius (1/193). Among these species, a high frequency of $S$. aureus $(100 \%)$ was found in samples of handmade coalho cheese and S. xylosus $(87.5 \%)$ and S. cohnii ssp. cohnii (50\%) in samples of industrialized coalho cheese (Figure 1). 
FIGURE 1. FREQUENCY OF THE STAPHYLOCOCCUS SPECIES, IDENTIFIED THROUGH THE API ${ }^{\circledR}$-STAPH SYSTEM, IN THE HANDMADE AND INDUSTRIALIZED COALHO CHEESE.

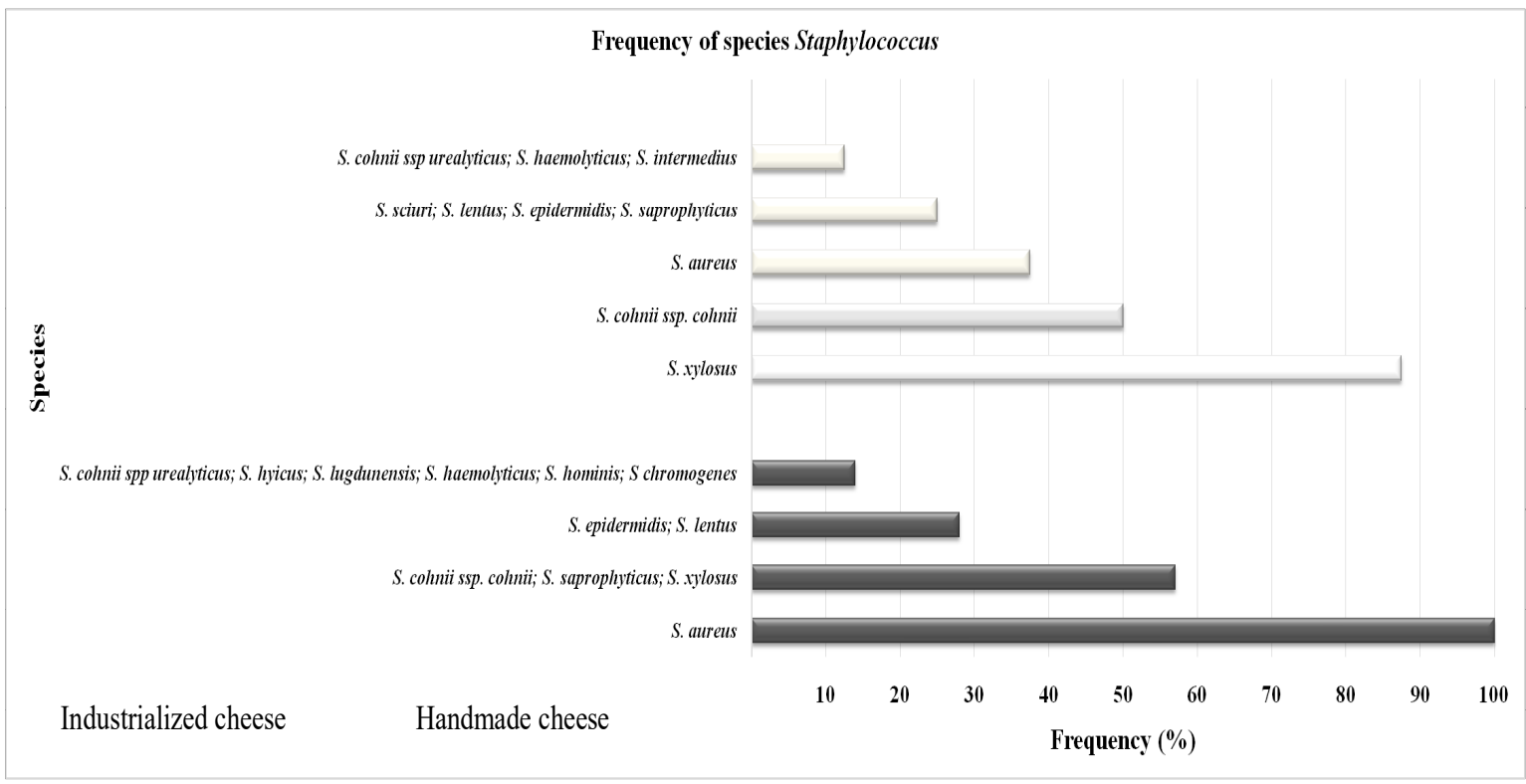

The high frequency of $S$. aureus $(100 \%)$ in samples of handmade coalho cheese can be associated to contamination of raw milk, re-contamination after pasteurization, inadequate storage conditions and the handler, which may favor the dissemination of this bacterium in food. It is important to highlight that $S$. aureus has stood out as the main species responsible for the cases of staphylococcal food poisoning outbreaks due to the possibility of producing staphylococcal enterotoxins.

Study carried out by Andrade et al. (2011), demonstrated that Staphylococcus species prevalent in samples of coalho cheese were: S. aureus $(100 \%)$, S. xylosus $(87,5 \%)$ and S. cohnii subsp. cohnii (50\%).

In another study, Vieira (2017) evaluated 179 isolates obtained at the colonial cheese sold in Porto Alegre, Brazil, and found the following species in 33\% of the samples: Staphylococcus equorum (10), S. vitulinus (6), S. hyicus (4), S. saprophyticus (4), S. epidermidis (3), S. carnosus (1), S. carnosus subsp. carnosus (1), S. capitis (1), S. chromogenes (1), S. fleurettii (1), S. haemolyticus (1), S. succinus subsp. casei (1) and S. warneri (1).

The high frequency of strains of coagulase-negative staphylococci such as $S$. xylosus, S.cohnii ssp. cohnii, S. saprophyticus, S. epidermidis and S. lentus detected in samples of coalho cheese, demonstrates the need of a re-evaluation of the microbiological standards established by Brazilian legislation.

In 40 isolates of $S$. aureus, evaluated by PCR, the amplification of the fragment by 132 bp was found, specifically for the femA gene, in 95\% (38/40) of the strains tested. This result demonstrates greater specificity and discriminatory power of genetic analysis.

In a similar study, Silva (2015) evaluated strains of S. aureus coagulase positive and negative isolated from cheese and detected the presence of the femA gene in $97,5 \%$ (39/40) of the isolates tested. Hassan et al. (2008) evaluated three molecular markers, among these the femA, for the detection of $S$. aureus and observed in the 45 strains tested the gene amplification.

The presence of enterotoxin encoding genes were observed in $49.5 \%$ (47/95) of the strains tested (Table 2). Among the 47 strains with SEG and SEH enterotoxin encoding genes SEG and $\mathrm{SEH}$, it was found a prevalence of the seh gene in $53.2 \%$ (25/47) of the isolates, nine of which were handmade and 16 of which were industrialized. 
TABLE 2. RESEARCH OF THE STAPHYLOCOCCI ENTEROTOXIN ENCODING GENES IN STRAINS OF STAPHYLOCOCCUS ISOLATED FROM HANDMADE AND INDUSTRIALIZED COALHO CHEESE SAMPLES

\begin{tabular}{cccc}
\hline Cheese & Quantity of Strains & Coagulase & Amplified Genes \\
\hline Handmade & 20 & + & $\operatorname{seg}(2) ; \operatorname{seh}(5)$ \\
& 25 & - & $\operatorname{seg}(9) ; \operatorname{seh}(4)$ \\
\hline $\begin{array}{c}\text { Industrialized } \\
\text { Total strains } \\
\text { evaluated }\end{array}$ & 20 & + & $\operatorname{seg}(2) ; \operatorname{seh}(15)$ \\
\hline
\end{tabular}

* Values in parenthesis indicate the quantity of strains that amplified one of the genes.

The gene seg was detected in $46.8 \%$ (22/47) of the isolates, 11 in each type of cheese. The genes encoding enterotoxin SEA, SEB, SEC, SED, SEE, SEI, SEJ and SEL were not detected in the isolates studied. These results indicate that the occurrence of the Staphylococcus spp enterotoxin encoding genes isolated from coalho cheese, was not very diverse.

Among the species with coagulase-negative and enterotoxigenic potential that will amplify a fragment for the seg and seh genes, we can highlight: S. cohnii ssp. cohnii, S. cohnii spp. urealyticus, S. chromogenes, S. epidermidis, S. hominis, S. hyicus, S. lentus, S. lugdunensis, S. saprophyticus and S. xylosus (Table 3). The presence of enterotoxigenic Staphylococcus species in samples of coalho cheese, both handmade and industrialized, may represent a potential danger to health because of the potential of causing staphylococcal food poisoning to consumers.

Rall et al. (2008) detected genes (sea, seb, sec, sed, see, seg, seh, sei and sej) encoders of staphylococcal enterotoxins in staphylococcal 57 strains isolated from raw and pasteurized milk and found the prevalence of genes seg (11 strains), followed by sei (10 strains) and seh and sej ( 3 strains each). In another study, Acosta et al. (2017) researched the genes (sea, seb, sed, seg, seh and sei) encoders of enterotoxins in strains of $\mathrm{S}$. aureus, isolated from milk, and observed the presence at last one of these genes in $48,1 \%(13 / 27)$ of the strains studied and the frequency of genes sea was $33.3 \%$, seh $18.5 \%$, sei $11.1 \%$ and sed $7.4 \%$.

Freitas et al. (2009) researched staphylococcal enterotoxin encoding genes in strains of Staphylococcus coagulase-positive and negative, isolated from coalho cheese, and detected the presence of the following genes: tst (1/18), sec (2/18), sed (2/18), seg (4/18), seh (3/18), sei (4/18) and sej $(2 / 18)$ in $90 \%(18 / 20)$ of the strains. Morandi et al. (2009) also investigated enterotoxin encoding genes (sea, sec, sed, seg, seh, sei, sej and sel) in 122 strains of Staphylococcus spp., isolated from dairy products and found the presence of the genes sea (13), sed (3), seg (1), seh (3) and sei (1) in 20 coagulase-positive strains.

Kérouanton et al. (2007) evaluated the potential of enterotoxigenic strains of $S$. aureus associated with outbreaks of staphylococcal food poisoning in France and found the presence of one or more of the genes studied in 29 strains. There was the prevalence of the gene sea (23/29) and sed (12/29). In another study, Luz (2009) found in strains of Staphylococcus aureus, isolated from milk and coalho cheese, the presence of the genes seg, seh, sei and sej in $93.6 \%$ of strains evaluated. 
These results indicate that enterotoxigenic strains of Staphylococcus found in foods require greater attention because they put food security in danger. However, the high frequency of enterotoxin encoding genes, from Staphylococcus coagulase-positive and negative strains, detected in samples of coalho cheese, represent the risk of it causing staphylococcal food poisoning to consumers.

TABLE 3. OCCURRENCE OF GENES SEG E SEH IN STAPHYLOCOCCUS SPP. ISOLATED FROM DIFFERENT SAMPLES OF HANDMADE AND INDUSTRIALIZED COALHO CHEESE.

\begin{tabular}{|c|c|c|c|}
\hline Cheese & Brand & Species & Amplified Genes \\
\hline \multirow{9}{*}{ Handmade } & A & $\begin{array}{l}\text { S. chromogenes (1)*, S. epidermidis (1), } \\
\text { S. saprohyticus (1) }\end{array}$ & $3 \operatorname{seh}$ \\
\hline & B & S. aureus (1) & $1 \mathrm{seg}$ \\
\hline & C & $\begin{array}{l}\text { S. cohnii ssp urealyticus (1), S. hominis (1), } \\
\text { S. saprohyticus (1) }\end{array}$ & 3 she \\
\hline & \multirow{2}{*}{$\mathrm{D}$} & $\begin{array}{l}\text { S. cohnii ssp cohnii (2), S. lentus (1), } \\
\text { S. saprophyticus (1), S. xylosus (1) }\end{array}$ & 5 seg \\
\hline & & S. aureus (1) & 1 she \\
\hline & \multirow{2}{*}{ E } & $\begin{array}{l}\text { S. cohnii ssp cohnii (1), S. epidermidis (1), } \\
\text { S. lugdunensis (1) }\end{array}$ & 3 seg \\
\hline & & S. aureus (1) & 1 she \\
\hline & \multirow{2}{*}{$\mathrm{F}$} & S. aureus (1), S. hyicus (1) & $2 \mathrm{seg}$ \\
\hline & & S. aureus (1) & 1 she \\
\hline \multirow{8}{*}{ Industrialized } & $\mathrm{H}$ & S. xylosus (4) & 4 seg \\
\hline & \multirow{2}{*}{1} & S. xylosus (3), S. lentus (2) & $5 \mathrm{seg}$ \\
\hline & & S. xylosus (1) & 1 she \\
\hline & \multirow{2}{*}{$\mathrm{J}$} & S. lentus (1) & $1 \mathrm{seg}$ \\
\hline & & S. cohnii spp cohnii (1) & 1 she \\
\hline & $\mathrm{L}$ & S. aureus (2) & 1 seg; 1 she \\
\hline & $\mathrm{N}$ & S. aureus (3) & 3 she \\
\hline & $\mathrm{O}$ & S. aureus (10) & 10 she \\
\hline
\end{tabular}

* Values in parenthesis indicate a quantity of strains of the species that amplified a fragment for the gene.

\section{CONCLUSIONS}

- The diversity of the species of coagulase-positive and negative present in coalho cheese is represented by S. aureus, S. xylosus, S. cohnni ssp. cohnii, S. saprophyticus, S. epidermidis, S. hyicus, S. lentus, S. sciuri, S. cohnii spp. urealyticus, S. haemolyticus, S. chromogenes, S. lugdunensis, S. hominis and $S$. intermedius.

- There is a high frequency of Staphylococcus aureus in handmade coalho cheese. As for the industrialized cheese, there is a higher frequency of coagulase-negative species, with predominance of $S$. xylosus, S. cohnni ssp. cohnii.

- The genotypic identification (PCR) confirmed $95 \%$ of the strains of $S$. aureus identified by biochemical tests. The genes seg and seh, encoders of the new enterotoxins (SEG and $\mathrm{SEH}$ ), occurs in Staphylococcus species isolated from coalho cheese.

- The gene seg was predominant in the coagulase-negative species such as S. cohnni spp. cohnii, S. cohnni ssp. urealyticus, S. chromogenes, S. epidermidis, S. hominis, S. hyicus, S. lentus, S. lugdunenis, S. saprophyticus and S. xylosus. While the seh gene was predominant in $S$. aureus. 
- The high frequency of coagulase-negative staphylococcal strains detected in samples of coalho cheese, suggests the need for a re-evaluation of the microbiological standards established by Brazilian legislation for cheeses that refer only to coagulase- positive Staphylococcus.

\section{THANKS}

The authors would like to thank Embrapa Tropical Agro-industry for the financial support and the Scientific Development Support Foundation of Ceará (Fundação Cearense de Apoio ao Desenvolvimento Científico - FUNCAP) for granting the scholarship.

\section{REFERENCES}

1 Acosta, A. C.; Santos, S.J. S.; Albuquerque, L.; Soares, K.D. A.; Mota, R.A.; Medeiros, E.S. (2017). Frequência de genes codificadores de toxinas em Staphylococcus aureus isolados de leite de tanques expansão comunitários. Pesq. Vet. Bras. v.37. n.7, 691-696.

2 Andrade, A.P.C.; Borges, M.F.; Figueiredo, E. A. T.; Machado, T.F.; Porto, B.C. (2011). Perfil de Staphylococcus Coagulase Positiva e Negativa Contaminantes de Queijo de Coalho Bol. de Pesq. e Desenvl., vol 52, 18p.; Embrapa Agroindústria Tropical.

3 Ângelo, F.F.; Arcuri, E.F.; Andrade, N.J.; Merhi, C.M.; Lange, C.C. (2007). Avaliação da presença de genes para enterotoxinas, pela técnica de PCR multiplex, em Staphylococcus aureus isolados de mastite bovina na Zona da Mata Mineira. Rev. Inst. Latic. Când. Tost. 62: 410-413.

4 Bannerman, T. L. Staphylococcus, Micrococcus, and other catalase positive Coci that grow aerobically. (2003) In: MURRAY, P.R.; BARON, E. J.; JORGENSEN, J. H.; PFALLER, M. A.; YOLKEN, R. H. (Ed.). Manual of clinical microbiology. 8th ed. Washington: ASM. v. 1, Chap. 28, p. 384-404.

5 Bayles, K. W.; landolo, J. (1989). Genetic and molecular analyses of the gene encoding staphylococcal enterotoxin D. Journal of Bacteriology. 171: 4799-4806.

6 Bennett, R. W.; Lancette, G. A. (2001). Staphylococcus aureus. Available at: http://www.fda.gov/Food/ScienceResearch/ LaboratoryMethods/BacteriologicalAnalyticalManualBAM/UCM071429.

7 Betley, M. J.; Mekalanos, J. J. (1985). Staphylococcal enterotoxin A is encoded by phage. Science. 4729: 185-187.

8 Bohach, G.A.; Schievert, P.M. (1987). Nucleotide sequence of the staphylococcal enterotoxin C 1 gene and relatedness to other pyrogenic toxins. Mol. Genet. Genomics. 209:15-20.

9 Couch, J. L.; Soltis, M. T.; Betley, M. J. (1988). Cloning and nucleotide sequence of the type E staphylococcal enterotoxin gene. J Bacteriol. 170: p. 2954-2960.

10 Cremonesi, P.; Vimercati, C.; Castiglioni, B.; Luzzana, M.; Ruffo, G. (2006). Identification of enterotoxins genes in Staphylococcus aureus isolates from bovine and caprine milk. Vet. Res. Comm. 30: 241-243.

11 Dantas, D. S; Araujo, A. M; Santos, J. O; Santos, R. M. S; Rodriques, O. G. (2013). Qualidade Microbiológica do Queijo de Coalho Comercializado no Município de Patos, Estado da Paraiba. ACSA - Agropecuária Cientifica no Semiárido, $\mathrm{v}, 9, \mathrm{n}, 3, \mathrm{p} .110-118$.

12 Evangelista-Barreto, N.S; Santos, G.C.F.; Souza, J.S.; Bernardes, F.S.; Silva, I.P. (2016). Queijos artesanais como veículo de contaminação de Escherichia coli e estafilococos coagulase positiva resistentes a antimicrobianos. $R$. Bras. de Hig. e Sani. Anim. v.10, n.1, p. $55-67$

13 Freitas, M. F. L.; Luz, I. S.; Pinheiro Júnior, J. W.; Duarte, D. A. M.; Vasconcelos, A. M. M.; Ribeiro, A. R.; Mota, R. A.; Balbino, T. C. L.; Stamford, T. L. M . (2009). Detecção de genes toxigênicos em amostras de Staphylococcus spp. isoladas de queijos de coalho no estado de Pernambuco. Ciênc. Tecnol. Alim. 29:1-5.

14 Hassan, S. R. U.; Verma, V.; Qazi, G. N. (2008). Evaluation of three different molecular markers for the detection of Staphylococcus aureus by polymerase chain reaction. Food Microbiol. 25: 452-459.

15 Jones, C.L.; Khan, S.A. (1986). Nucleotide sequence of the enterotoxin B gene from Staphylococcus aureus. J. Bacteriol. 166: 20-33.

16 Kérouanton, A. Hennekinne, J. A.; Letertre, C.; Petit, L.; Chesneau, O.; Brisabois, A.; De Buyser, M. L. (2007). Characterization of Staphylococcus aureus strains associated with food poisoning outbreaks in France. Int. J. Food Microbiol. 115: 369-375. 
17 Luz, I.S. (2009). Molecular characterization of toxins in Staphylococcus aureus isolated from milk and "coalho" cheese in cities from the Agreste Region of Pernambuco. Rev. Inst. Med. Trop. 51: 140.

18 Mazzariol, A.; Lo Cascio, G.; Kocsis, E.; Maccacaro, I.; Fontana, R.; Cornaglia, G. (2012). Outbreak of linezolid-resistant Staphylococcus haemolyticus in an Italian intensive care unit. Eur. J. Clin. Microbiol. Infect. Dis., v. 31, n. 4, p. $523-527$.

19 Mehrotra, M.; Wang, G.; Johnson, W.M. (2000). Multiplex PCR for detection of genes for Staphylococcus aureus enterotoxins, exfoliative toxins, toxic shock syndrome toxin 1, and methicillin resistance. J. Clin. Microbiol.. 38:10321035.

20 Morandi, S.; Brasca, M.; Andrighetto, C.; Lombardi, A.; Lodi, R. (2009). Phenotypic and genotypic characterization of Staphylococcus aureus strains from Italian dairy products. Int. J. Microbiol. Article ID 501362: 7 pages.

21 Munson, S.H.; Tremaine, M.T.; Betley, M.J.; Welch, R.A. (1998). Identification and characterization staphylococcal enterotoxins of type $\mathrm{G}$ and from Staphylococcus aureus. Infect. Immun. 66:3337-3348.

22 Oliveira, K.M. L; CARVALHO, J.B.; RAMOS, L.P.S.; GELATTI, L. C. (2015). Presença de Staphylococcus aureus em queijos artesanais comercializados na cidade de Uruaçu-Goiás. Ver. de Cien. Hum., Saud e Tecnol. v.8, n.2., 63-71.

23 Oliveira, K. A.; Evêncio Neto, J.; de Paiva, J. E.; de Melo, L. E. H. (2010). Qualidade microbiológica do queijo de coalho comercializado no município do Cabo De Santo Agostinho, Pernambuco, Brasil. Arq. Inst. Biol. 77:435-440.

24 Pelissier, M.R.; Klein, C.S.; Ascoli, K.R.; Zotti, T.R.; Arisi, A.C.M. (2009). Ocurrence of Staphylococcus aureus and multiplex PCR detection of classic enterotoxin genes in cheese and meat products. Braz. J. Microbiol. 40: $145-148$.

25 Vieira, T. R. (2017). Pesquisa de Staphylococcus spp. Coagulase negativa em queijo colonial inspecionado: identificação, perfil de genes de enterotoxinas clássicas e de resistência à penicilina e à meticilina. Dissertação. 85 f. Porto Alegre.

26 Rall, V. M. L.; Vieira, F. P.; Rall, R.; Vieitis, R. L.; Fernandes J. R. A.; Candeias, J. M. G.; Cardoso, K. F. G; Araujo JR, J. P. (2008). PCR detection of staphylococcal enterotoxins genes in Staphylococcus aureus strains isolated from raw and pasteurized milk. Vet. Microbiol. 132:408-413.

27 Ren, K.; Bannan, J. D.; Pancholi, V.; Cheung, A. L.; Robbins, J. C.; Fischetti, V. A.; Zabriskie, J. B. (1994) Characterization and biological properties of a new staphylococcal enterotoxin. J. Experim. Med. 180:1675-1683.

28 Rosec, J. P.; Gigaud, O. (2002). Staphylococcal enterotoxin genes of classical and new types detected by PCR in France. Intern. J. of F. Microb., Amsterdam, v. 77, n. 1/2, p. 61-70.

29 Silva, A. C. (2015). Ocorrência de Genes de Enterotoxinas Estafilocócicas Clássicas Em Queijo de Coalho Artesanal. Dissertação (Mestrado em Medicina Veterinária) - Universidade Federal de Campina Grande, Centro de Saúde e Tecnologia Rural, 73f.

30 Silva Júnior, F. J. T. M. (2017). Pesquisa de Staphylococcus coagulase positivo em queijos tipo coalho produzidos com leite cru e comercializados em três municípios do agreste paraibano. Trabalho de conclusão de curso (Graduação em Medicina Veterinária) - Centro de Ciências Agrárias. Universidade Federal da Paraíba, Areia. $26 \mathrm{f}$.

31 Tigre, D. M.; Borelly, M.A.N. (2011). Pesquisa de Estafilococos coagulase-positiva em amostras de "queijo coalho" comercializadas por ambulantes na praia de Itapuã R. Ci. med. biol., Salvador, v.10, n.2, p.162166.

32 Ünal, N.; Çinar, O. D. (2012). Detection of stapylococcal enterotoxin, methicillin-resistant and PantonValentine leukocidin genes in coagulase-negative staphylococci isolated from cows and ewes with subclinical mastitis. Trop. Anim. Health Prod., v. 44, n. 2, p. 369-375.

33 Zhang, S.; landolo, J. J.; Stewart, G. C. (1998). The enterotoxin D plasmid of Staphylococcus aureus encodes a second enterotoxin determinant (sej). FEMS Microbiol. Lett. 168:227 -233. 